\title{
EDITORIALS
}

\section{To Silence the Trumpeter}

The notes rang out loud and clear over the lawns and shrubberies interspersing our concrete jungle-a clarion call for all to hear. At first we wondered how anyone could be so admirably bold, and feared that neighbours would object; a wild man or undisciplined youth, perhaps, and surely not long to remain unchallenged. But day after day the diminutive trumpeter prevailed, and we could see him standing serenely erect on a balcony half-way up a many-storeyed apartmentblock. Perhaps his shortness of stature was a basis for boldness-or was he a dwarf or partly-grown child? Anyhow, each day around lunch-time and often again into the long summer evening, we continued to enjoy his selection of airs most tastefully chosen and expertly presented-delighted also that no concrete-jungle Scrooge had prevailed in silencing our benefactor. And then it stopped-not quite, but except for a few furtive notes on intermittent occasions. Later there was one glorious resumption which engendered applause from several quarters-but also, we divined, sufficient opposition from somebody to see the entire performance ended from that last rapturous day.

And so it is in the wider world: those who have a message for mankind that may be unwelcome to merely a small faction thereof, have somehow to be silenced-be they prophet or scientific innovator, bold demographer or environmental realist. (This even goes for preachers of altruistic peace and goodwill among men, as readers of the Holy Bible will know full-well.) Their message, if not universally understood and welcomed, and also conforming to the fashions of the day, must be submerged or anyway left publicly unheeded. And yet the furtive notes of the faithful may continue, and the glorious blast resume-in the case of our environmental movement, somehow to be heeded and triumph in the end through saving the world if not itself.

The historical figures who have spoken out have often fared little or no better than such mythical ones as Phaethon*, and now there is the case of an outstanding and outspoken colleague who is said to be not allowed to enter, and surely not allowed to speak publicly in, what should be the leading bastion of his academic field and faith; instead he is persecuted by its inmates and jealous countrymen. Where a prophet is without honour in his native land or immediate domain, it is the native land or domain that is apt to suffer through its callous lack of recognition and concomitant action. But now, with modern communications and mass-media making the human-inhabited world practically one, it is this world as a whole which suffers (and is surely destined to suffer far more) through lack of appreciation of its parlous state.

We are thinking, naturally and indeed perforce, of the effect of burgeoning human population as frequently warned about in many quarters including our own columns, and expertly epitomized in the guest editorial by Professor Paul $\mathbf{R}$. Ehrlich \& Dr John P. Holdren in our corresponding issue of least year. That we have repeatedly been asked for (and gladly granted) permission to reprint this and other articles dealing with such matters is gratifying -as is the fact that we are by no means alone in this neo-Malthusian call which can clearly no longer be silenced. But the call of the environmental movement is less easy to carry through in the face of looming problems concerning energy, of the anarchical tendencies accompanying human population swarming and possibly leading to such outcomes as 'the Beirut Syndrome' of people killing one another in increasing numbers, of impending shortages of food, raw materials, and living-space, of the general absence of funding for 'good works', and for other reasons too numerous to mention here.

Yet the clarion call for due environmental concern based on sound ecological and other scientific principles must continue, and so must the research and other work to back it; even if at times they recede into the background, environmental problems will always remain with us-probably in approximate proportion to human propulation, even though Man is getting wiser as times go on and crises loom. Thus he is beginning to realize that profligate use of the all-toolimited space and other possibilities offered by a finite globe cannot go on increasing for ever, while many seemingly essential resources are irreplaceable and 'once for all'. Yet when, only a little more than a decade ago, we relinquished our last academic appointments to try and do our bit towards alerting the world to the emerging dangers of ever-increasing population pressures, there were no full ministries of environment in the governments of the world. Now there are many, and the tendency seems to be for all governments to have such representations, whatever they may be called. Often they are highly factitious and scarcely an answer to our call; but at least they acknowledge its central theme of concern for the environment and, consequently, the future of Man and Nature, and hence constitute steps in the right direction.

To this extent and in some other ways the environmental movement has caught on and our trumpets of exhortation to more and more ecologically-sound action now blast forth from many quarters practically throughout the world. Nor must we ever run out of breath or allow them to be silenced, but always play on - with ever-sweeter and more welcome tunes as the world learns to adjust itself to the environmental message and in due course bring in what may be called the ecological era.

N. P.

\begin{abstract}
* Son of the Sun-god Helios of ancient Greek mythology which narrates that Phaethon, a notoriously bad driver who was unable to control the horses of the sun-chariot, ventured too near to the Sun and, like Icarus when the wax fastening on his wings melted in the Sun's heat and he fell back to Earth, paid the price with his life. Phaethon is also mentioned in the telling poem by our eminent Advisory Editor on matters pertaining to Meteorology and Climatology, published on page 308 of this issue.
\end{abstract}

Environmental Conservation, Vol. 3, No. 4, Winter 1976-(C) 1976 The Foundation for Environmental Conservation-Printed in Switzerland. 